\title{
Knowledge, attitude, and practice of resident doctors about medical research in BJ Medical College, Pune, Maharashtra
}

\author{
Pranav J. Satav*, Uma N. Wankhede
}

Department of Obstetrics and Gynecology, BJGMC and SGH Pune, Maharashtra, India

Received: 24 April 2017

Accepted: 22 May 2017

*Correspondence:

Dr. Pranav J. Satav,

E-mail: drpranavsatav99@gmail.com

Copyright: (C) the author(s), publisher and licensee Medip Academy. This is an open-access article distributed under the terms of the Creative Commons Attribution Non-Commercial License, which permits unrestricted non-commercial use, distribution, and reproduction in any medium, provided the original work is properly cited.

\section{ABSTRACT}

Background: Every doctor should strive to contribute to the generation of evidence by conducting research. A review of literature showed that the data regarding knowledge, attitude, practice towards medical research among resident doctors pursuing post graduate studies in India is lacking. The objective of the study was to assess medical research related knowledge, attitude and practice of resident doctors in BJ Medical college, Pune, Maharashtra.

Methods: With written informed consent of the participant, a cross-sectional survey was conducted at BJ Medical College, Pune, Maharashtra using structured and pre-validated questionnaire. We enrolled all 102 resident doctors pursuing their second and third year residency in various subjects. Two residents have not given written consent and excluded from the study $(\mathrm{N}=100)$. All participants were provided with sufficient time of 7 days to fill the KAP questionnaire. In case of more than 5 unanswered questions, the participant was excluded from the study. The data was expressed in percentage and analyzed by Microsoft Office Excel 2007.

Results: The concept of research hypothesis was known to $48 \%$ of the residents. $85 \%$ of the residents were aware of the procedure to obtain informed consent. $82 \%$ of the residents agreed that patient outcome improves with continued medical research. Although 56\% of the residents were interested in conducting research in future, $60 \%$ had made paper/poster presentations and only $15 \%$ had publications. 'Lack of time' (60\%), 'lack of research curriculum' (26\%) and 'inadequate facilities' (30\%) were stated as major obstacles for pursuing research.

Conclusions: Our study finds that residents have a fair knowledge about research. They also showed a positive attitude toward research, but they fail to transform their knowledge and attitude into actual practices.

Keywords: Attitude, Knowledge, Research, Resident

\section{INTRODUCTION}

The rapidly evolving medical science of today necessitates that physicians and surgeons keep abreast with the latest developments. Every doctor should strive to contribute to the generation of evidence by conducting research. For carrying out a research study adequate knowledge, practical skills and development of right attitude are crucial. ${ }^{1}$ The benefits of resident research are manifold. It helps promote evidence based medicine and quality patient care, provide skills for lifelong learning, enhance resident's analytic skills and develop critical thinking. Surveys of program directors and residents reveal seven barriers to research during residency: insufficient resident interest, limited resident time, paucity of mentors, limited faculty time, lack of resident research skills, absence of a research curriculum and inadequate funding. ${ }^{2}$ When we consider the medical research scenario in India, we find that quality research in India is limited, and number of research articles published in this field are also few. In order to encourage research orientation in resident doctors, currently MCI 
has made it mandatory to present one poster, to read one paper at a national/state conference and to present one research paper which should be published/accepted for publication/sent for publication during the period of his postgraduate studies. A review of literature showed that the data regarding knowledge, attitude, practice towards medical research among resident doctors pursuing post graduate studies in India is lacking. ${ }^{3}$ It is a common observation that a majority of resident doctor's conduct research projects during the second or third year of residency. So, decided to undertake a cross sectional study to assess research related knowledge, attitude, practice of resident doctors..$^{4-5}$

\section{METHODS}

This cross-sectional survey was conducted at BJ Medical College Pune. We enrolled 100 resident doctors pursuing their second and third year residency in MD, MS courses. The KAP questionnaire consisted of 21 multiple choice questions, out of which question number 1 to 3 are knowledge based, question number 4-11 are attitude based and question number 12 to 18 are practice based questions. They are designed specifically to answer the awareness about medical research. All participants were provided sufficient time to fill the questionnaire. The study objectives and other details were explained to the residents at the time of giving the questionnaires. In case of more than 5 unanswered questions, a participant was excluded from the study. The data was expressed in percentage and analyzed by Microsoft Office Excel 2007.

\section{RESULTS}

Out of 100 residents enrolled in the study, 60 were in the second year of residency while the remaining 40 were in the third year. A total of 56 were from clinical specialities and 44 were from pre-and para clinical specialities. The concept of research hypothesis was known to $48 \%$ of the residents. $62 \%$ of the residents were aware of approval for conducting clinical research using new drugs. $85 \%$ of the residents were aware of the procedure to obtain informed consent (Table 1).

Table 1: Knowledge domain: percentage of responses (N=100).

\begin{tabular}{|l|l|}
\hline Questions & $\begin{array}{l}\text { Correct response } \\
\text { by resident } \\
\text { doctors }(\%)\end{array}$ \\
\hline $\begin{array}{l}\text { From whom to seek approval } \\
\text { for conducting clinical research } \\
\text { using new drugs in India? }\end{array}$ & 62 \\
\hline $\begin{array}{l}\text { Do you know about Medline? } \\
\text { Do you know about informed } \\
\text { consent? }\end{array}$ & 55 \\
\hline
\end{tabular}

$82 \%$ of the residents agreed that patient outcome improves with continued medical research.52\% agreed that research training should be mandatory. Although
$81 \%$ of the residents agreed that they should be involved in medical research, $60 \%$ agreed that a separate time should be allotted in the curriculum for research activities (Table 2).

Table 2: Attitude of resident doctors regarding medical research $(\mathrm{N}=100)$.

\begin{tabular}{|lcc|}
\hline $\begin{array}{l}\text { Questions } \\
\text { Positive }\end{array}$ & $\begin{array}{c}\text { Negative } \\
\text { response } \\
\text { response } \\
\%\end{array}$ \\
$\begin{array}{l}\text { Does patient outcome improve } \\
\text { with continued medical } \\
\text { research? }\end{array}$ & 81 & 19 \\
\hline $\begin{array}{l}\text { Training in medical research } \\
\text { methodology should be made } \\
\text { compulsory? }\end{array}$ & 52 & 48 \\
$\begin{array}{l}\text { Resident doctors should be } \\
\text { involved in medical research? }\end{array}$ & 81 & 19 \\
\hline $\begin{array}{l}\text { Undertaking research increases } \\
\text { burden on already over worked } \\
\text { resident doctors? }\end{array}$ & 60 & 40 \\
\hline $\begin{array}{l}\text { Research should be mandatory } \\
\text { criteria for appearing for final } \\
\text { examination of a post graduate } \\
\text { curriculum? }\end{array}$ & 40 & 60 \\
\hline $\begin{array}{l}\text { Can research doctors plan and } \\
\text { conduct research project } \\
\text { without supervision? }\end{array}$ & 15 & 85 \\
\hline $\begin{array}{l}\text { Research time should be } \\
\text { allotted separately while } \\
\text { planning the postgraduate } \\
\text { residency curriculum? }\end{array}$ & 60 & 40 \\
\hline $\begin{array}{l}\text { Will you carry out research in } \\
\text { future? }\end{array}$ & 56 & 44 \\
\hline
\end{tabular}

Although $56 \%$ of the residents were interested in conducting research in future, $44 \%$ had made paper/poster presentations and only $15 \%$ had publications. Only $28 \%$ of the residents stated that they read journals regularly (Table 3 ).

Table 3: Responses of resident doctors regarding research practices $(\mathrm{N}=100)$.

\begin{tabular}{|lcc|}
\hline Questions & Yes \% & No \% \\
\hline $\begin{array}{l}\text { Do you have experience in } \\
\text { writing protocol? }\end{array}$ & 32 & 68 \\
\hline $\begin{array}{l}\text { Do you have any publications in } \\
\text { journal? }\end{array}$ & 15 & 85 \\
\hline $\begin{array}{l}\text { Have you presented any research } \\
\text { paper/poster in a national } \\
\text { conference? }\end{array}$ & 44 & 56 \\
$\begin{array}{l}\text { Are you reading journals } \\
\text { regularly? }\end{array}$ & 28 & 72 \\
\hline $\begin{array}{l}\text { Have you participated workshop } \\
\text { on research methodology? }\end{array}$ & 91 & 09 \\
\hline
\end{tabular}

'Lack of time' was cited as a major obstacle for research by $60 \%$ of the residents, of which $56 \%$ felt that training 
in their speciality consumed most of their time. $26 \%$ of the residents admitted 'lack of research curriculum' as an obstacle while $30 \%$ of them stated 'inadequate facilities' for medical research as an obstacle (Table 4).

Table 4: Obstacles preventing residents from doing medical research $(\mathrm{N}=100)$.

\begin{tabular}{|l|l|}
\hline Reasons & $\begin{array}{l}\text { Residents' } \\
\text { response (\%) }\end{array}$ \\
\hline Institutional reasons & \\
\hline Lack of interest by faculty & 04 \\
\hline Inadequate mentors / assistant & 04 \\
\hline Lack of research curriculum & 26 \\
\hline Inadequate financial support & 06 \\
\hline Lack of time & 60 \\
\hline Personal reasons & 10 \\
\hline Lack of interest & 56 \\
\hline $\begin{array}{l}\text { Learning of post-graduate subjects } \\
\text { takes a lot of time }\end{array}$ & 30 \\
\hline $\begin{array}{l}\text { Inadequate facilities for medical } \\
\text { research }\end{array}$ & 04 \\
\hline $\begin{array}{l}\text { Personal commitments like family } \\
\text { problems, marriage and so on }\end{array}$ & \\
\hline
\end{tabular}

\section{DISCUSSION}

Our study revealed that knowledge about the need and prerequisites of research was fairly good among resident doctors. Most of the residents showed a positive attitude toward medical research and intended to do research in future career. But there was disparity found with regard to their attitude and actual practice. Only a few were actively involved in making scientific contributions to research. Results are comparable to study done in Faisalabad and Mumbai. This discrepancy between attitude and practice is a cause of concern and merits furtherinvestigation. ${ }^{6}$ The major reasons cited for poor research activity in our study are lack of time, lack of research curriculum and inadequate facilities for medical research. While in Pakistan lack of resources (31\%) and poor research training at undergraduate and postgraduate level $(17 \%)$ were the top reasons for poor research activity. ${ }^{6}$ These are different from the Western settings where lack of time and lack of interest were more important obstacles to research as compared to poor training, although improper training and high workload were also cited. ${ }^{7}$ However two studies that were carried out in Canada and Pakistan reflected a contrasting attitude of residents that a majority of time in residency should be spent learning the clinical aspects of their speciality and they were unwilling to sacrifice personal time for research. Post-graduate students are introduced to the concept of designing and conducting research during residency. Medical research carried out by undergraduate and postgraduate students in India is disappointing compared to developed countries. In Germany where research is an integral part of undergraduate medical curriculum, medical students were involved in $28 \%$ of the publications in a particular institution. ${ }^{8}$ 'Research training' should be made as an integral part of M.B.B.S curriculum by introducing short duration (one week) research training programme and conducted at the beginning of internship so that student do not face additional examination burden. ${ }^{9}$ Lack of research exposure and training underscores need to review both undergraduate and postgraduate curriculum so that some specific educational intervention is incorporated. We believe that faculty members who are actively involved in research can serve as powerful 'role models' for post-graduate students. Training programs for faculty members can be helpful in creating 'incubators' for research. ${ }^{10}$ 'Lack of time' was cited as the main obstacle by majority of resident doctors. This obstacle can be overcome in several ways. The first step is to identify potential bottlenecks in the research pathway and attempt to facilitate them. Residents often have difficulty in recruiting participants or collecting data, and performing statistical analysis. Data collection can be facilitated by using existing data sets, collecting data electronically. Medical colleges should conduct workshops for training in research methodology. Projects can be further accelerated by providing separate time for residents of clinical responsibilities and allowing them to focus on research and committed to the completion of a research project. ${ }^{2}$ Residents should be made aware of the importance of research and how research may be helpful in solving health problems of the community. Most of our medical colleges lack in terms of well-equipped laboratories and that is one of the main reasons why the students as well as the staff hardly gets any exposure to the newest technologies and the scope of biomedicine in the medical field. This lack of knowledge about the global scenario hindered the professors and the lectures to attempt any sort of research program in specialized area. Also, there is minimal initiation from the funding agencies to support any medical research. Lot of committees was formulated during the years to take care of the manpower development in this area. However, no committee will address the critical need of research based medical education.

The limitations of this study are that it was conducted at one institution involving a limited number of trainees. Therefore, the findings cannot be generalized. We could not include the questions that reflected a broad range of topics in the research for evaluation of the knowledge aspect of resident doctors.

\section{Funding: No funding sources Conflict of interest: None declared \\ Ethical approval: Not required}

\section{REFERENCES}

1. Bhatt A. The challenges of growth in clinical research: Training gap analysis. Mumbai: Pharma Bioworld. 2005:56-8. 
2. Rothberg MB. Overcoming the obstacles to research during residency: What does it take? JAMA. 2012;308(21):2191-2.

3. Rehan N. Medical research in Pakistan. J Coll Physicians Surg. 2003;13:617.

4. Pawar DB, Gawde SR, Marathe PA. Awareness about medical research among resident doctors in a tertiary care hospital: A cross-sectional survey. Perspectclin res. 2012;3(2):57-61.

5. Post-graduate medical education regulations; 2000. Available from: http://www.mciindia.org/rules and regulations /post- graduate medical education regulations 2000aspx.

6. Aslam F, Qayuum MA, Mahmud H, Qasim R, Haque IU. Attitudes and practices of postgraduate medical trainees towards research-a snapshot from Faisalabad. JPMA. 2004;59:534.

7. Gill S, Levin A, Djurdjev O. Obstacles to residents conducting research and predictors of publication. Acad med. 2001;76:477.
8. Cursiefen C, Altunbas A. Contribution of medical student research to the medlineindexed publications of a German medical faculty. Med. Educ. 1998;32:439-40.

9. Deo MG. Need for research oriented medical education in India. Indian J Med Res. 2009;30:105-7.

10. Shankar PR, Chandrasekhar TS, Mishra P, Subish P. Initiating and strengthening medical student research: Time to take up the gauntlet. Knowledge, attitude, and practice of resident doctors about medical research. Kathmandu University Med J. 2006;4(13):135-8.

Cite this article as: Satav PJ, Wankhede UN.

Knowledge, attitude, and practice of resident doctors about medical research in BJ medical college, Pune, Maharashtra. Int J Reprod Contracept Obstet Gynecol 2017;6:2969-72. 